\title{
A Novel Raw Starch Hydrolyzing Thermostable $\alpha$-Amylase Produced by Newly Isolated Bacillus mojavensis SO-10: Purification, Characterization and Usage in Starch Industries
}

\author{
Sadin Ozdemir ${ }^{1 *}$, Sema Aguloglu Fincan ${ }^{2}$, Adem Karakaya ${ }^{3}$, Baris Enez ${ }^{\mathbf{4}}$. \\ $1 *$ Mersin University, Technical Science Vocational School, Food Processing Programme, TR-33343 Yenisehir, \\ Mersin, Turkey; \\ ${ }^{2}$ Dicle University, Faculty of Science, Department of Biology,21280 Diyarbakir, Turkey; \\ ${ }^{3}$ Department of Biology, Faculty of Arts and Science, Siirt University, 56100 Siirt, Turkey; \\ ${ }^{4}$ Bingol University, Technical Science Vocational School, Laborant and Veterinary Health Program, 1200, Bingol, \\ Turkey.
}

\begin{abstract}
The aim of this study is the production, purification, and characterisation of thermostable raw starch hydrolyzing $\alpha$ amylase produced by Bacillus mojavensis SO-10. The maximum production conditions of a-amylase were found at $36^{\text {th }}$ hour, $35^{\circ} \mathrm{C}$ and $\mathrm{pH}$ 7.0. We utilized three steps to purify the thermostable $\alpha$-amylase and as a result, 34-fold and $18 \%$ yield were obtained. The molecular weight of purified $\alpha$-amylase was determined as $73 \mathrm{kD} . T$ The $K_{m}$ and $V_{\max }$

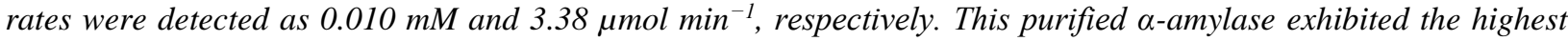
activity at $\mathrm{pH}$ 5.0-6.0 and $70^{\circ} \mathrm{C}$ and showed stability over a wide variety of $\mathrm{pH}$ and temperature at 4.0-8.0, and 40 $50{ }^{\circ} \mathrm{C}$, respectively. The thermostable purified $\alpha$-amylase exhibited stability in the presence of denaturing agents and heavy metal ions. The purified enzyme hydrolyzed the raw starches of corn and wheat grains in the ratio of $36.7 \%$ and $39.2 \%$ respectively. The end-yields of soluble starch hydrolysis were analyzed by thin-layer chromatography $(T L C)$. In addition, the usage of purified $\alpha$-amylase in clarification of apple juice and domestic washing detergent industries were evaluated.
\end{abstract}

Key words: $\alpha$-Amylase; Raw starch; Thin-Layer Chromatography (TLC); Detergents; Apple Juice Clarification

\footnotetext{
*Author for correspondence: sadinozdemir@mersin.edu.tr
} 


\section{INTRODUCTION}

Amylase (EC 3.2.1.1, 1, 4- $\alpha$-D-glucan-glucanohydrolase) is an extracellular enzyme that hydrolyzes starch and glycogen molecules ${ }^{1}$. It breaks down the $\alpha-1,4$ bonds in starch molecules into glucose, maltose, maltotriose and $\alpha$-limit dextrine ${ }^{2,3}$. Amylase is used primarily in the food industry for the preparation of maltose syrup and clarification of various drinks. In addition, amylase is generally used in other industries like biorefinery, paper, detergents, textiles and pharmaceuticals ${ }^{4-7}$.

Starch-hydrolyzing enzymes as amylase play an important role in carbohydrate metabolisms. It is a well-known fact that $\alpha$-amylases degrade the starches. They can also be utilized to form a variety of major products with various physical and chemical qualities for foods and pharmaceuticals ${ }^{8}$.

As native starch is not dissolve in water at low temperature, many conventional processes are carried out at high temperature and pressure for gelatinization of the raw starch. These processes require an extreme-energy input, so the production cost of starch-based products is increased. To decrease the starch processing cost, effective utilization of natural resources and viscosity problems, direct hydrolysis of starch at low temperature is desirable ${ }^{9}$. The significance of enzymatic saccharification of raw starch without heating has become well recognized due to energy savings and low cost of starch processing 10-12. This has generated the discovery of some raw starch degrading enzymes (RSDE) that can directly hydrolize raw starch below the gelatinization temperature of starch ${ }^{13}$. In recent years, a worldwide interest has been focused on the raw starch digesting amylases, which would be of value to simplify the process of starch conversion.

The most widely utilized thermostable $\alpha$-amylases are obtained from mesophilic and thermophilic microorganisms which are considered to be potential sources of thermostable $\alpha$-amylases of industrial significance ${ }^{14}$. They have been indicated from a large range of microorganisms from a few species of genus Bacillus and Streptomyces ${ }^{15}$. Bacillus is usually utilized for the commercial production of thermostable $\alpha$-amylases.

The present research reports the production, purification and biochemical characterizations of an $\alpha$-amylase obtained from Bacillus mojavensis SO-10. This purified $\alpha$-amylase displayed attractive characteristics such as temperature and $\mathrm{pH}$ stability and chemical agents' resistance. In addition, the purified amylase was utilized in some industrial starch processes like raw starch hydrolyzing, detergents and apple juice clarification.

\section{MATERIALS AND METHODS}

\section{Culture conditions}

Bacillus mojavensis SO-10 were grown in $250 \mathrm{~mL}$ glass bottle containing $50 \mathrm{~mL}$ Nutrient Broth (NB) media. The culture media's pH was adjusted with $0.1 \mathrm{M} \mathrm{HCl}$ or $\mathrm{NaOH}$ to $\mathrm{pH} 7.0$, and glass bottles were autoclaved at $121^{\circ} \mathrm{C}$ for 15 minutes. After being autoclaved, every bottle was inoculated with $0.5 \mathrm{~mL}\left(3.1 \times 10^{8} \mathrm{CFU} / \mathrm{mL}\right)$ of cell suspension. The fermentation media was cultured at $35^{\circ} \mathrm{C}$ on a shaker at $120 \mathrm{rpm}$.

\section{Enzyme activity}

$\alpha$-Amylase activity was studied by determining the quantity of reducing sugars using 3, 5 dinitrosalicylic acid (DNS) process ${ }^{16}$. According to this process, $0.5 \%$ starch solution $(200 \mu \mathrm{L})$ was incubated with $100 \mu \mathrm{L}$ crude enzyme solution or $5 \mu \mathrm{L}$ purified enzyme for $30 \mathrm{~min}$ at $70{ }^{\circ} \mathrm{C}$. The reaction was stopped by adding DNS reagent and reaction solution was boiled for $5 \mathrm{~min}$. After leaving it for cooling at room 
Purification and charactarization of amylase

temperature, $3 \mathrm{~mL}$ of pure water was added to the reaction mixture and spectrophotometric determination was measured at $489 \mathrm{~nm}$. One unit of $\alpha$-amylase activity was determined as the quantity of enzyme that produced $1 \mathrm{mmol}$ of reducing sugars maltose per minute.

\section{Impact of incubation time on $\alpha$-amylase production}

The influence of various time courses on enzyme production was assayed at $35^{\circ} \mathrm{C}$ in $\mathrm{NB}$ at $\mathrm{pH} 6.0$ and $35^{\circ} \mathrm{C}$ in a shaker at $120 \mathrm{rpm}$. A $2 \mathrm{~mL}$ of fermentation culture media was collected at various incubation times $(0-96 \mathrm{~h})$. Then, the media was centrifuged at $7.000 \mathrm{rpm}$ for $10 \mathrm{~min}$. The upper solution was tested for determination of $\alpha$-amylase activity according to DNS process.

\section{Influence of fermentation temperature and $\mathrm{pH}$ on enzyme production}

The sterile NB fermentation media was incubated at different temperature between 20 to $55{ }^{\circ} \mathrm{C}$ at $\mathrm{pH} 7.0$ and $120 \mathrm{rpm}$ in a shaker for 36 hours and enzyme assay was evaluated as mentioned above. The optimum fermentation media's $\mathrm{pH}$ for production of $\alpha$-amylase was examined at $\mathrm{pH}$ ranges of 4.0, 5.0, 6.0, 7.0, 8.0, 9.0, and 10.0 on optimum culture conditions. After incubation, fermentation media was centrifuged and the upper solution was tested for enzyme activity.

\section{Purification of $\alpha$-amylase}

The crude enzyme was exposed to $\left(\mathrm{NH}_{4}\right)_{2} \mathrm{SO}_{4}$ up to $80 \%(\mathrm{w} / \mathrm{v})$ saturation and allowed to precipitate at $4{ }^{\circ} \mathrm{C}$. The precipitates were centrifuged at $10.000 \mathrm{rpm}$ for $15 \mathrm{~min}$. The precipitate was dispersed in $0.1 \mathrm{M}$ potassium phosphate buffer ( $\mathrm{pH} 7.0)$, and dialyzed overnight at $4{ }^{\circ} \mathrm{C}$. The dialyzed enzyme solution was applied to a DEAE (Diethylaminoethyl) cellulose (DE 32) column (flow rate $15 \mathrm{~mL} / \mathrm{h}$ ).

\section{Protein analysis on SDS-PAGE}

The purity of $\alpha$-amylase was determined on SDS-PAGE according to Laemmli process utilizing $10 \%$ polyacrylamide gel ${ }^{17}$.

\section{Determination of kinetic parameters}

The purified $\alpha$-amylase was tested at different starch concentrations from $0.5 \%$ to $2 \%$ for determination of $\mathrm{K}_{\mathrm{m}}$ and $\mathrm{V}_{\max }$. The $\mathrm{K}_{\mathrm{m}}$ and $\mathrm{V}_{\max }$ were calculated from the reciprocal plot of starch concentration (S) versus velocity $(\mathrm{V})$.

\section{Influence of temperature on purified $\alpha$-amylase activity and stability}

The purified enzyme activity at various temperatures was studied by incubating the reaction mixture at temperature ranging between $20{ }^{\circ} \mathrm{C}$ to $90{ }^{\circ} \mathrm{C}$. The temperature stability of purified enzyme was also experimented by pre-incubating the enzyme between $40-70{ }^{\circ} \mathrm{C}$ for $30,60,90,120,150$, and $180 \mathrm{~min}$ and the remaining purified $\alpha$ amylase activity was determined.

\section{Influence of $\mathrm{pH}$ and $\mathrm{pH}$ stability}

The optimal $\mathrm{pH}$ of the enzyme was experimented by incubating the enzyme reaction solution at $\mathrm{pH}(3.0,4.0,5.0,6.0,7.0,8.0,9.0,10.0$, and 11.0). For measuring $\mathrm{pH}$ stability of purified $\alpha$-amylase, the enzyme was pre-incubated between various $\mathrm{pH}$ ranges of 4.0 to 8.0 for $30-240 \mathrm{~min}$. The purified $\alpha$-amylase activity in standard reaction mixture was used as control. 
Effects of inhibitors and different metal ions on purified enzyme activity The effect of different metal ions such as $\mathrm{MnCI}_{2}, \mathrm{ZnCI}_{2}, \mathrm{MgCI}_{2}, \mathrm{CuCI}_{2}, \mathrm{CaCI}_{2}, \mathrm{FeCI}_{2}$, $\mathrm{HgCI}_{2}$ and various inhibitors such as EDTA (ethylenediaminetetraacetic acid), PMSF (phenylmethanesulfonyl fluoride), $\beta$-mercaptoethanol and DTT (dithiothreitol) on purified $\alpha$-amylase was studied. The purified $\alpha$-amylase was pre-incubated with 1.5 $\mathrm{mM}$ metal ions and 1,5 and $10 \mathrm{mM}$ inhibitors for $30 \mathrm{~min}$ at $37^{\circ} \mathrm{C}$ and the standard $\alpha$ amylase activity assay was carried out.

\section{Thin layer chromatography (TLC)}

The purified $\alpha$-amylase was incubated with $1 \%$ soluble wheat starch to determine the end-products of hydrolyzed soluble starches at various incubation time $(15,30$ and $240 \mathrm{~min}$ ). $3 \mu \mathrm{L}$ of end products of reaction were spotted on TLC plate (Merck). The end products of reaction were examined by pre-coated TLC plate with the solvent system of $\mathrm{n}$-butanol/methanol/ $\mathrm{H}_{2} \mathrm{O}(8: 4: 3, v / v / v)$. Spots were visualized by spraying a sulfuric acid/methanol solution $(1: 7, v / v)$, drying and heating at $95^{\circ} \mathrm{C}$ for $10 \mathrm{~min}$.

\section{Industrial applications of Purified $\alpha$-amylase Influence of detergents on purified $\alpha$-amylase activity}

Various detergent solutions (Omo, Tursil, and Alo) were prepared at $0.5 \%$ concentration. In this test, $50 \mu \mathrm{L}$ detergent solution, $200 \mu \mathrm{L}$ starch, and $10 \mu \mathrm{L} \alpha-$ amylase were mixed and incubated from $15 \mathrm{~min}$ to $120 \mathrm{~min}{ }^{8}$. The enzyme activity was assayed according to the DNS method as mentioned above.

\section{Raw starch degrading}

Wheat and corn raw starch grains were cleaned 3 times with distilled water to eliminate contaminants. The grains were dried and $1 \%$ of raw wheat and corn starch grain was suspended in $980 \mu \mathrm{L}$ of $0.1 \mathrm{M}$ buffer (citric acid) at $\mathrm{pH} 6.0$ and $10 \mu \mathrm{L}$ of purified $\alpha$-amylase was added. The purified $\alpha$-amylase was incubated with wheat and corn raw starch grains at $50{ }^{\circ} \mathrm{C}$ for $4 \mathrm{~h}$, and reaction solution was centrifuged. The upper solutions were examined to define released reduce sugars with DNS assay with maltose as the standard. The percentage of degrading of raw starch $(\mathrm{Rh})$ was calculated by the following formula:

$\mathrm{Rh}(\%)=\left(\mathrm{A}_{1} / \mathrm{A}_{0}\right) \times 100$,

where $A_{1}$ refers to the quantity of reducing sugar in the upper after the degrading, and $\mathrm{A}_{0}$ refers to the quantity of raw starch before the degrading ${ }^{18}$. After $4 \mathrm{~h}$ incubation, hydrolyzed starch of wheat and corn grains were cleaned with pure ethanol and dried. The dried starch grains were treated with iodine solution and photographed under the Olympus CX31 light microscope 400 times magnification.

The starch amounts of immature apple juices (green and red) and theirs clarification by purified enzyme

The detection of starch contents in immature apple juice was experimented according to the method defined by Carrín et al. ${ }^{19}$, and the usage of purified alpha amylase in the apple juice clarification industry was assayed.

\section{RESULTS AND DISCUSSION}

\section{Impact of time courses, temperature, and $\mathrm{pH}$ on $\alpha$-amylase production}

We tested the impact of fermentation course, temperature, and $\mathrm{pH}$ on $\alpha$-amylase production. It is well known that short incubation time is important for cheap production of enzyme in fermentation industry. The production of $\alpha$-amylase is demonstrated in Fig. 1. The production of the enzyme increased when the incubation time increased up to $36^{\text {th }}$. The maximum $\alpha$-amylase production was achieved with $36^{\text {th }}$ 
(Fig. 1a) and the enzyme production decreased after $36^{\text {th }}$. After this incubation period, there was a decrease in the production of $\alpha$-amylase. This is because the cells have reached the decline phase and displayed low $\alpha$-amylase synthesis. The decrease in the enzyme production may be due to consumption of the nutrients in the fermentation culture or due to accumulation of toxic by-products. The fermentation temperature and $\mathrm{pH}$ were also significant parameters, which clearly affect enzyme production. The fermentation temperature and $\mathrm{pH}$ were tested between 20 to $55^{\circ} \mathrm{C}$ and 4.0 to 10.0 respectively in an incubator shaker to define the temperature and $\mathrm{pH}$ influences on $\alpha$ amylase production. The highest $\alpha$-amylase production was determined at $35^{\circ} \mathrm{C}$. When the fermentation temperature went up higher than $35^{\circ} \mathrm{C}, \alpha$-amylase production diminished (Fig. 1b). The enzyme yield reduced $87.3 \%$, while the fermentation temperature increased from 35 to $50{ }^{\circ} \mathrm{C}$. The $\alpha$-amylase activity found to be increasing as the fermentation $\mathrm{pH}$ rose from 4.0 to 7.0 (Fig. 1c). This was followed by a slight reduction in $\alpha$-amylase activity above the 7.0. The highest enzyme activity was recorded at $\mathrm{pH}$ ranges of 6.0-7.0. The optimum fermentation conditions for $\alpha$-amylase production were recorded at $36^{\text {th }}$ hour, $35^{\circ} \mathrm{C}$ and $\mathrm{pH}$ 6.0-7.0 by B. mojavensis SO-B11.

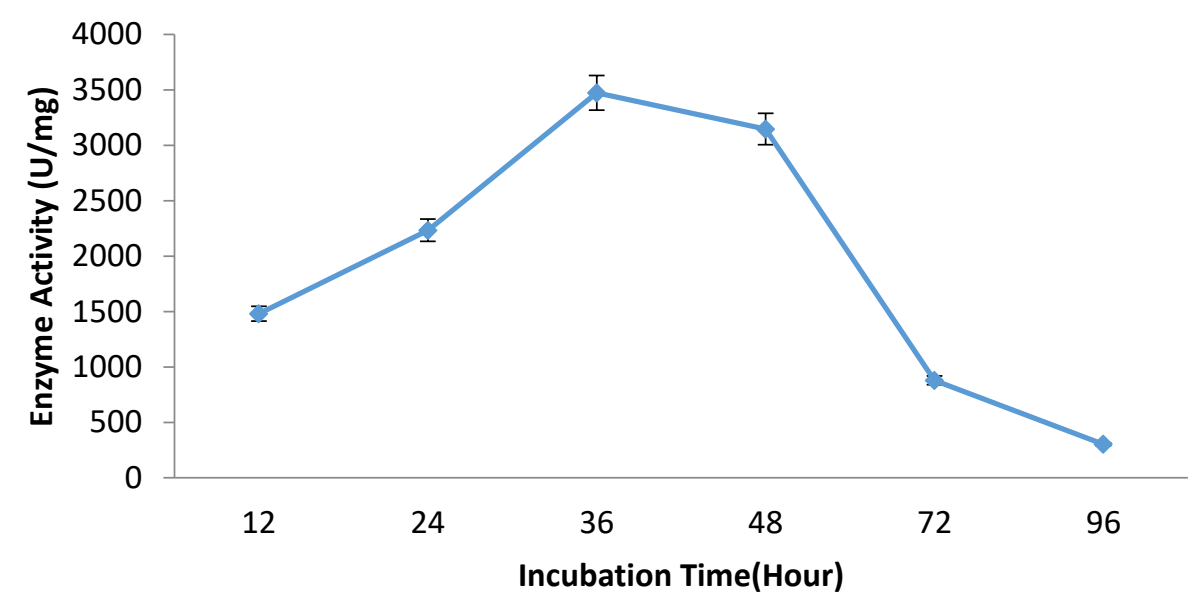

(a) 


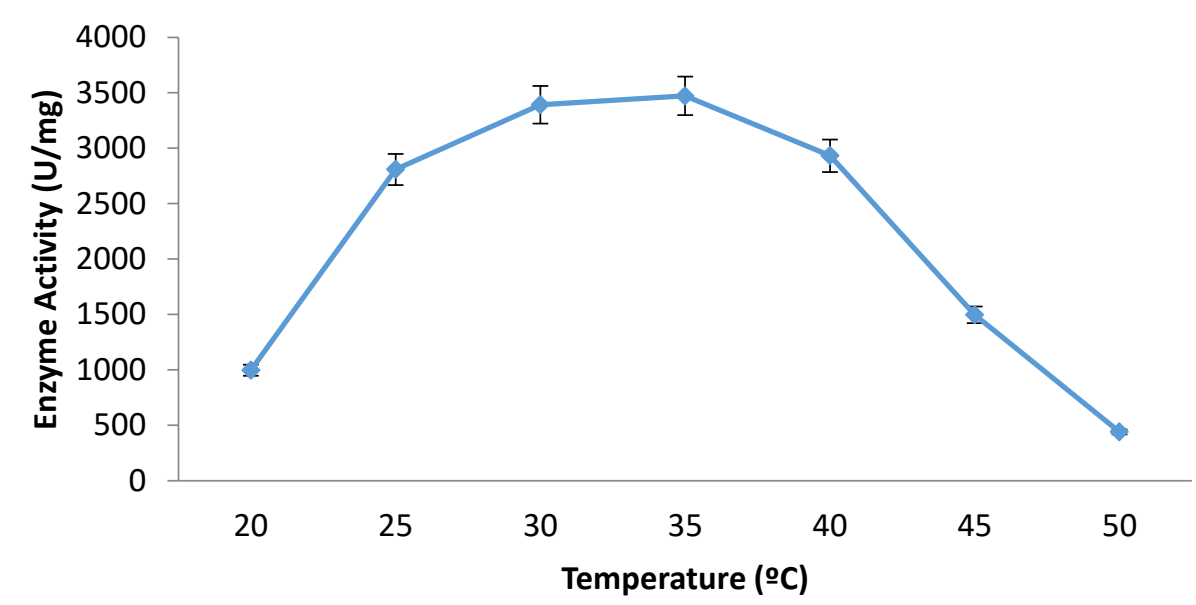

(b)

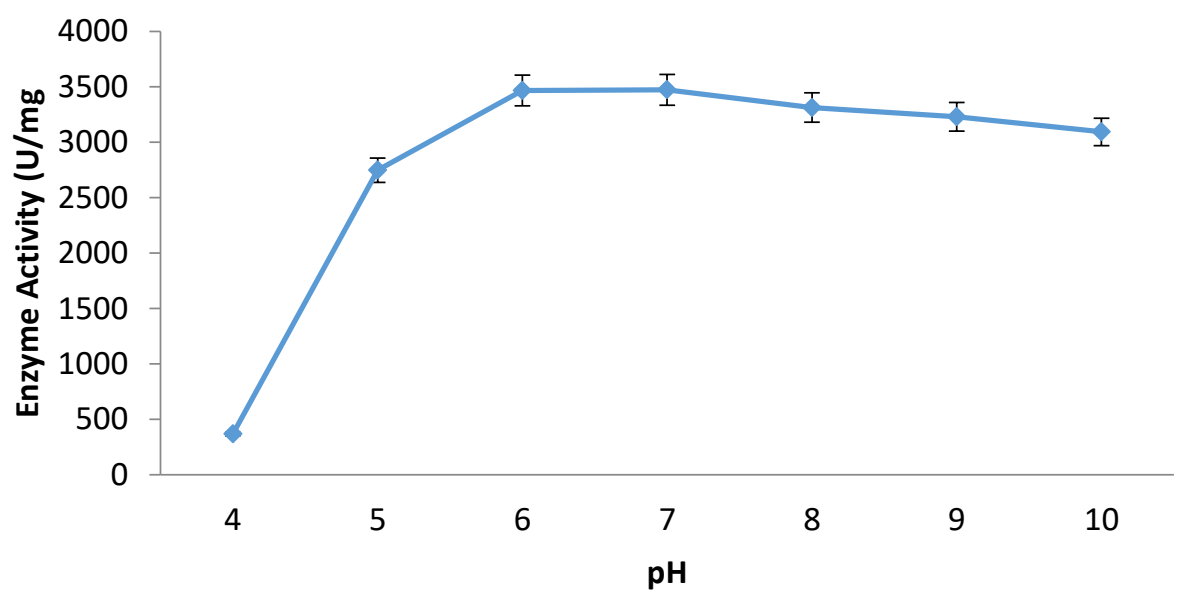

(c)

Figure 1 Impact of time cources (a), temperature (b), and $\mathrm{pH}$ (c) on $\alpha$-amylase production.

\section{Purification of $\alpha$-amylase}

The enzyme purification steps were $\left(\mathrm{NH}_{4}\right)_{2} \mathrm{SO}_{4}$ precipitation $(80 \%)$, dialyzed and DEAE-cellulose ion-exchange chromatography, respectively. The purification fold and yield were determined as $34 \%$ and $18 \%$ respectively completion of purification steps. The purification results are represented in Table 1 . The $\alpha$-amylase secreted by Geobacillus stearothermophilus was purified to homogeneity (65-fold and $46 \%$ yield) through a series of steps ${ }^{20}$. Recently, Xie et al. ${ }^{15}$ have indicated 13.1 purification fold and $7.0 \%$ yield, Abdel-Fattah et al. ${ }^{21}$ have pointed out 59.3 purification fold and 12.6 $\%$ yield, and Shukla and Singh ${ }^{22}$ have reported 37 purification fold and $16.8 \%$ yield using chromatography methods. 
Purification and charactarization of amylase

Table 1 Purification of amylase from B. mojavensis.

\begin{tabular}{|c|c|c|c|c|c|}
\hline Step & $\begin{array}{c}\text { Total } \\
\text { activity }(\mathbf{U})\end{array}$ & $\begin{array}{l}\text { Total protein } \\
(\mathbf{m g})\end{array}$ & $\begin{array}{c}\text { Specific activity } \\
\text { (U/mg) }\end{array}$ & $\begin{array}{c}\text { Yield } \\
(\%)\end{array}$ & Fold \\
\hline Crude extract & 283.374 & 188.444 & 1.504 & 100 & 1 \\
\hline $\begin{array}{l}\left.\mathrm{NH}_{4}\right)_{2} \mathrm{SO}_{4} \\
\text { precipitation/Dialysis }\end{array}$ & 106.705 & 8.746 & 12.201 & 38 & 8 \\
\hline DEAE-Cellulose & 50.929 & 0.982 & 51.870 & 18 & 34 \\
\hline
\end{tabular}

\section{Molecular mass determination on SDS-PAGE}

The molecular mass of the purified enzyme which appeared as a single band on SDSPAGE was found to be $73 \mathrm{kDa}$ (Fig. 2). Murakami et al. ${ }^{23}$ reported $\alpha$-amylases having molecular masses of 105 and $75 \mathrm{kDa}$, respectively. Asoodeh et al. ${ }^{24}$ determined the molecular weight of $\alpha$-amylase as $68.9 \mathrm{kDa}$. Michelin et al. ${ }^{25}$ demonstrated amylase as a single band of about $75 \mathrm{kDa}$ by SDS-PAGE. Another $\alpha$ amylase with molecular weight of $70 \mathrm{kDa}$ was indicated by Zafar et al. ${ }^{26}$. Different molecular masses of the $\alpha$-amylases from various Bacillus sp. ranging from 42 to $150 \mathrm{kDa}$ have been reported ${ }^{27}$.

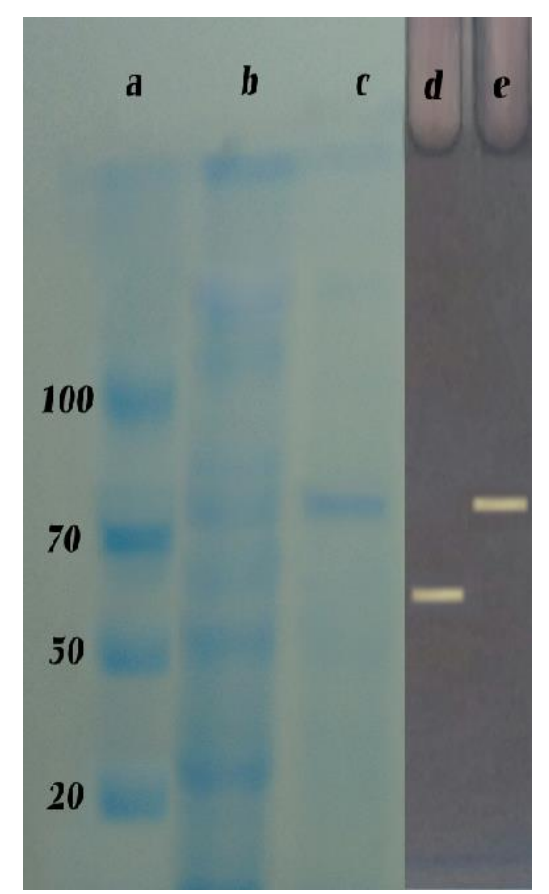

Figure 2 Molecular mass determination on SDS-PAGE. Lane a: standard proteins; Lane b: after dialyze c: purified enzyme from DEAE cellulose; Native-PAGE (using iodine stain) Lane d: standard a-amylase; Lane e: purified enzyme from DEAE cellulose.

\section{Determination of kinetic parameters}

Kinetic studies of $\alpha$-amylase were determined using soluble starch as substrate. The $\mathrm{K}_{\mathrm{m}}$ and $\mathrm{V}_{\max }$ values were estimated from a Lineweaver-Burk plot (Fig. 3). Values of $\mathrm{V} \max _{\text {ax }}$ and $\mathrm{K}_{\mathrm{m}}$ for the purified enzyme were $0,007964 \mathrm{mM}$ and 2, $77 \mu \mathrm{mol} \mathrm{min}{ }^{-1}$ respectively. Aguilar et al. ${ }^{28}$ declared the $\mathrm{K}_{\mathrm{m}}$ value of $\alpha$-amylase as $3.44 \mathrm{mg} / \mathrm{mL}$. Aguloglu Fincan et al. ${ }^{29}$ determined $\mathrm{K}_{\mathrm{m}}$ and $\mathrm{V}_{\max }$ as $0.005 \mathrm{mM}$ and $3.5 \mu \mathrm{mol} \mathrm{min}{ }^{-1}$, respectively. 


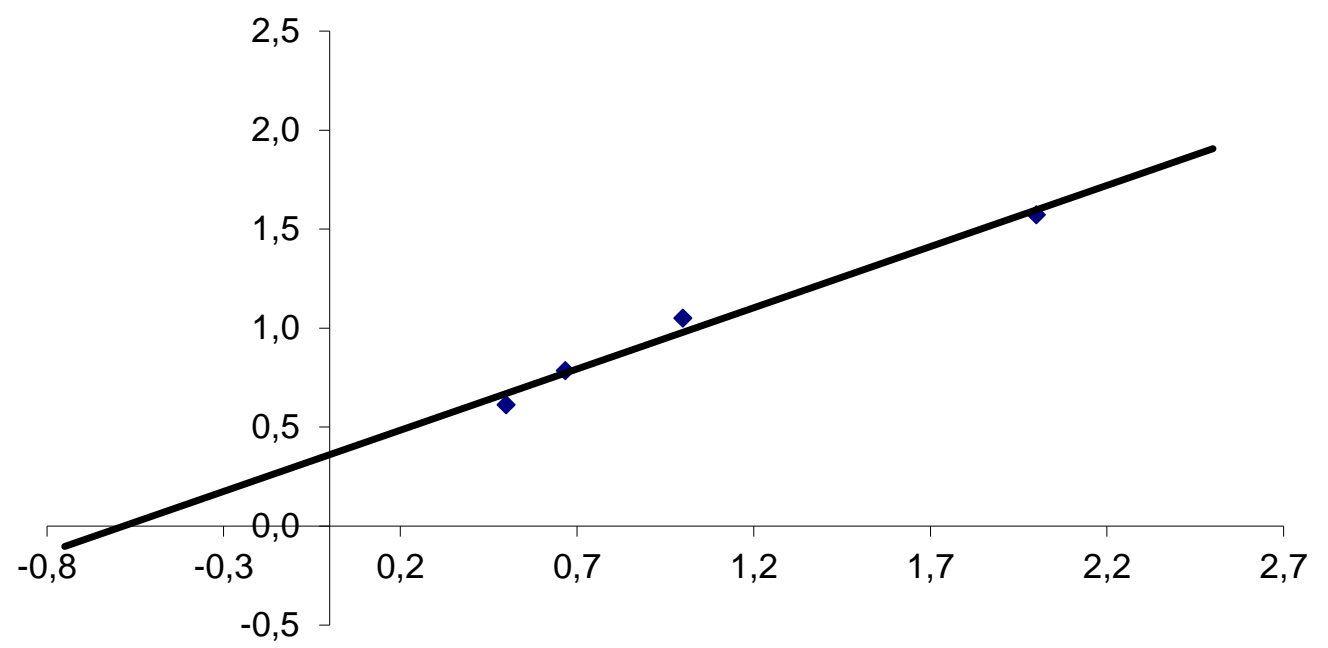

Figure 3 Lineweaver-Burk plot of purified $\alpha$-amylase from B. mojavensis.

Impact of temperature on purified amylolytic activity and stability

The impact temperature on amylolytic activity is shown on Fig. 4a, and the residual activities of purified enzyme were found as $37.1 \%, 70.9 \%, 82.7 \%, 90.3 \%$ and $97.6 \%$ at $20,30,40,50$, and $60{ }^{\circ} \mathrm{C}$, respectively. The purified amylase produced from $B$. mojavensis SO-B11 exhibited optimal activity at $70{ }^{\circ} \mathrm{C}$. The results revealed that the relative amylolytic activity sharply declined from $82.3 \%$ to $24.4 \%$ with increasing temperature from $80{ }^{\circ} \mathrm{C}$ to $90{ }^{\circ} \mathrm{C}$, respectively. The optimum temperature for $\alpha$ amylase from Bacillus sp. ferdowsicou ${ }^{24}$, Bacillus subtilis ${ }^{8}$ and Anoxybacillus flavithermus ${ }^{14}$ were found as 70,60 , and $70{ }^{\circ} \mathrm{C}$, respectively. This reveals that the optimum temperature of purified amylase obtained from B. mojavensis SO-B11 showed well parallelism with these studies. Thermal stability of the purified enzyme produced by $B$. mojavensis was examined by incubating the enzyme at different temperatures (30-180 $\mathrm{min})$. The results of thermal stability are represented in Fig. $4 \mathrm{~b}$. The purified enzyme was steady at temperature of $40{ }^{\circ} \mathrm{C}$ and $50{ }^{\circ} \mathrm{C}$ up to 180 $\min$. The $87.1 \%$ and $85.7 \%$ of residual enzyme activity was retained after $30 \mathrm{~min}$ of incubation at the temperature of $60{ }^{\circ} \mathrm{C}$ and $70{ }^{\circ} \mathrm{C}$, respectively. According to the results obtained from thermal stability of purified $\alpha$-amylase, the enzyme can be applied in brewing and food processing. 
Purification and charactarization of amylase

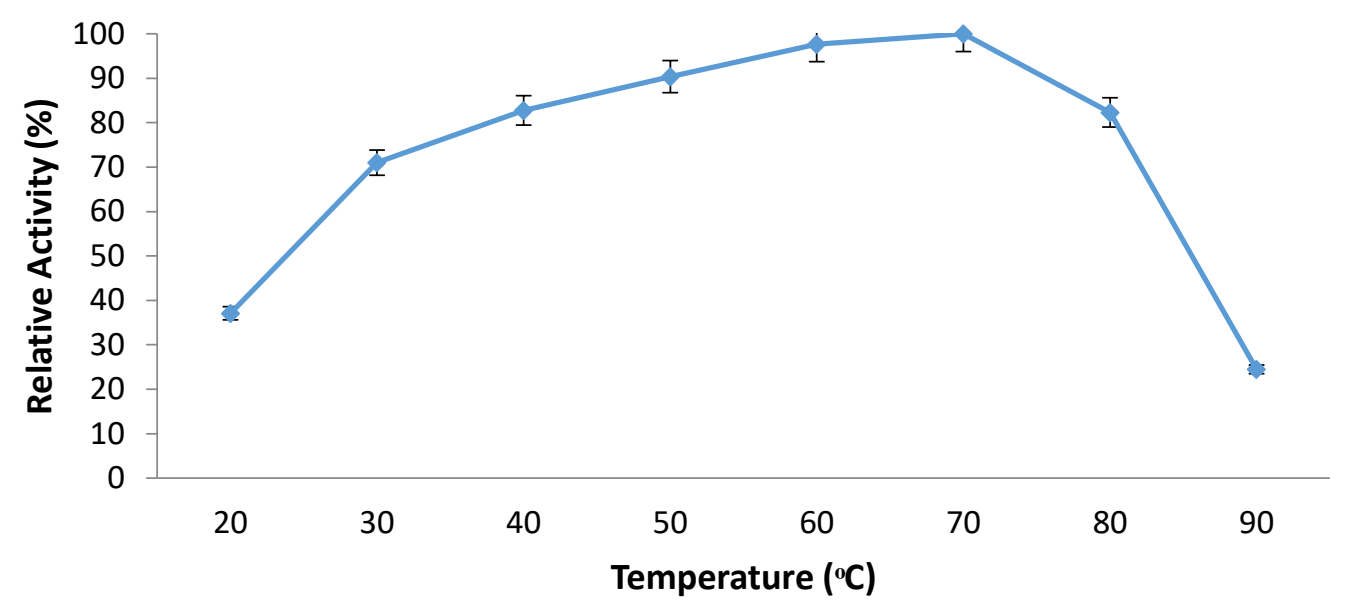

(a)

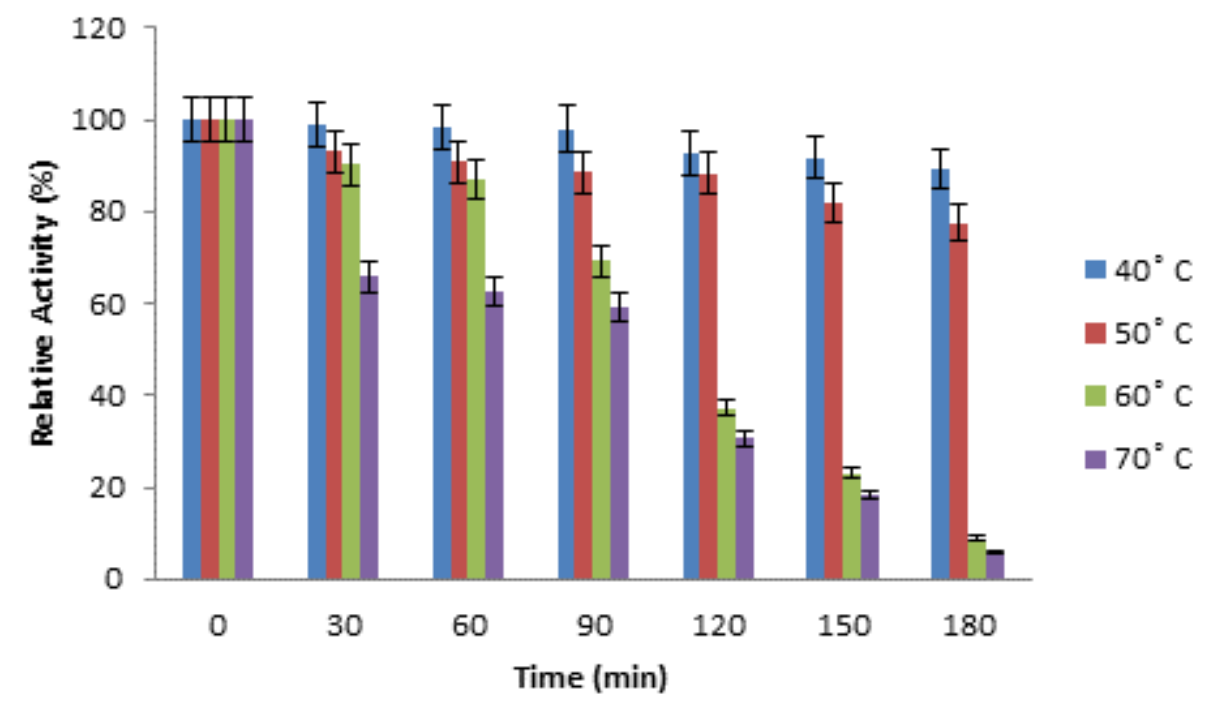

(b)

Figure 4 Impact of temperature on purified amylolytic activity (a) and stability (b).

Effect of $\mathbf{p H}$ on purified $\alpha$-amylase activity and stability

The $\mathrm{pH}$ profile of the purified enzyme activity is depicted in Fig. 5a. As shown in Fig. 5a, the amylolytic activity is nearly the same at $\mathrm{pH}$ 5.0-7.0. The amylolytic activity sharply decreased from $\mathrm{pH} 4.0$ to 3.0 and from $\mathrm{pH} 8.0$ to 9.0 . The purified $\alpha$-amylase showed optimum activity at $\mathrm{pH}$ 5.0-6.0. Parallel results were found by some researchers such as Hamilton et al. ${ }^{30}$, Sarikaya and Gürgün ${ }^{31}$ and Kikani and Singh ${ }^{32}$. The retained enzyme activity was about $96.2 \%$ at $\mathrm{pH}$ 7.0. The purified enzyme $\mathrm{pH}$ stability experimental results are depicted in Fig. 5b. The amylolytic activities did not significantly change between $\mathrm{pH}$ ranges of $4.0-8.0$ for $120 \mathrm{~min}$. The retained $\alpha$-amylase activities obtained from $B$. mojavensis SO-B11 were defined as $84.1 \%, 86.1 \%, 89.2 \%, 88.2 \%$ and $83.8 \%$ at $\mathrm{pH} 4.0,5.0,6.0,7.0$, and 8.0 respectively 
for $120 \mathrm{~min}$. These results indicated that purified novel enzyme can be utilized in starch saccharification and detergent industries.

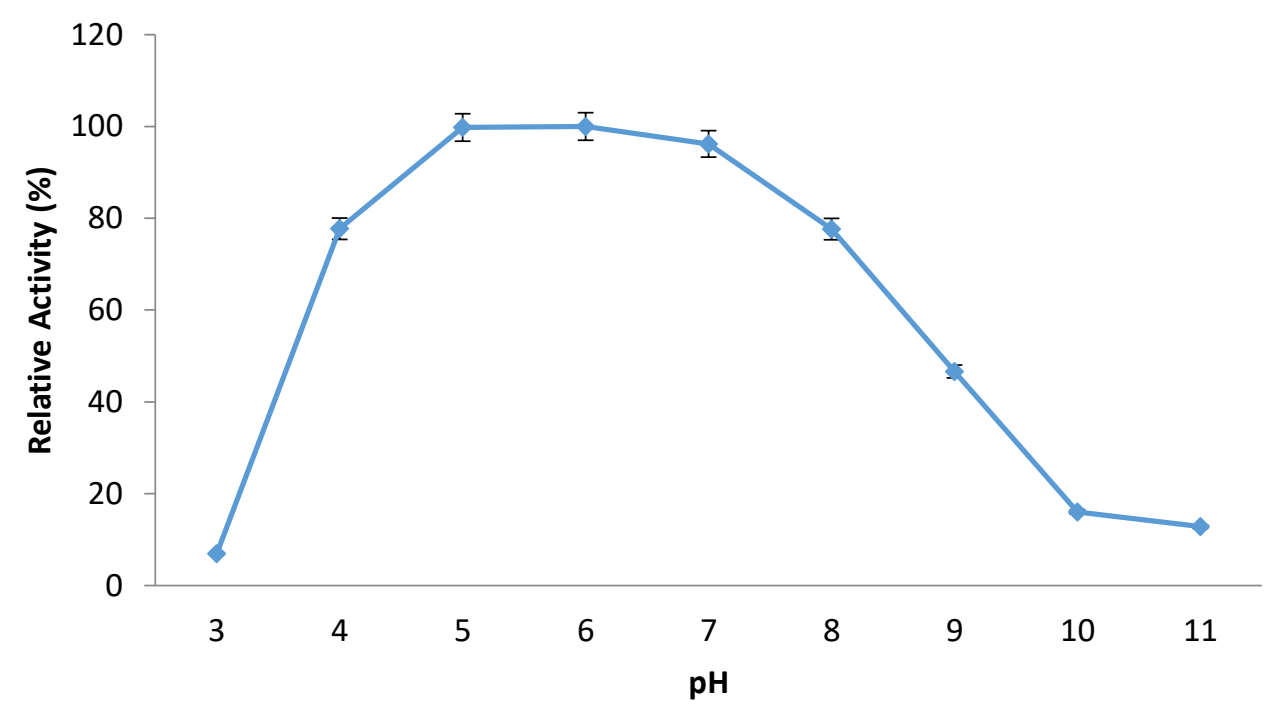

(a)

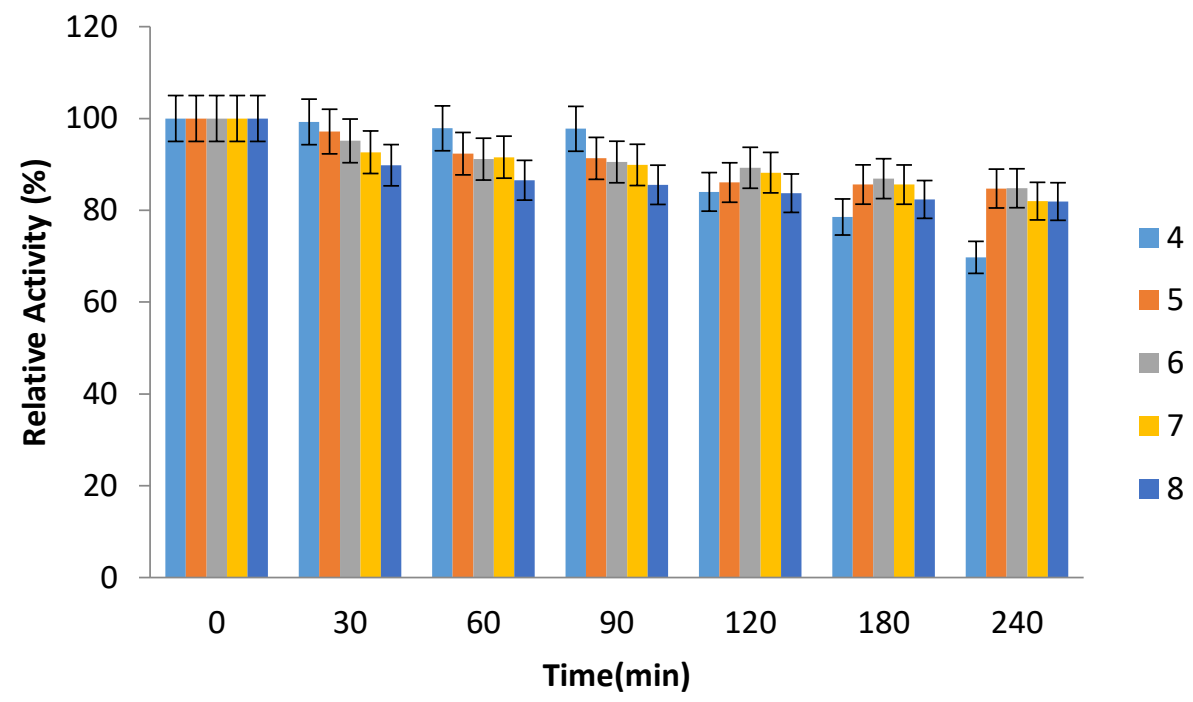

(b)

Figure 5 Effect of pH on purified amylolytic activity (a) and stability (b).

Effect of Different Cations and Inhibitors on Purified $\alpha$-Amylase Activity The influences of $\mathrm{Zn}^{2+}, \mathrm{Mg}^{2+}, \mathrm{Hg}^{2+}, \mathrm{Mn}^{2+}, \mathrm{Ca}^{2+}, \mathrm{Cu}^{2+}$ and $\mathrm{Fe}^{2+}$ and different inhibitors on purified $\alpha$-amylase activity are depicted in Table 2 . When compared with the control group, the enzyme activities in presence of $\mathrm{Zn}^{2+}, \mathrm{Mg}^{2+}, \mathrm{Hg}^{2+}, \mathrm{Mn}^{2+}, \mathrm{Ca}^{2+}$, $\mathrm{Cu}^{2+}$, and $\mathrm{Fe}^{2+}$ were determined as $82 \%, 86 \%, 38 \%, 119 \%, 121 \%, 79 \%$, and $94 \%$ respectively. The purified enzyme was activated by $\mathrm{Ca}^{2+}$ and $\mathrm{Mn}^{2+}$, but slightly inhibited by $\mathrm{Fe}^{2+}, \mathrm{Zn}^{2+}, \mathrm{Mg}^{2+}$, and $\mathrm{Cu}^{2+}$. Lin et al. ${ }^{33}$ suggested that enzyme was activated with $\mathrm{Ca}^{2+}$, while it was inhibited in the presence of $\mathrm{Hg}^{2+}$. The effect of various metal ions on purified $\alpha$-amylase activity was reported by Mamo and Gessesse ${ }^{34}$, Aguloglu Fincan and Enez ${ }^{20}$, and Liu et al. ${ }^{35}$. Our results are very close 
to their studies. The highest inhibitory effect was obtained with EDTA. This inhibition can reveal that the purified $\alpha$-amylase produced by B. mojavensis SO-B11 is a metalloenzyme. Our results completely match with the results obtained by other investigations on the $\alpha$-amylase ${ }^{15,36,37}$. PMSF and $\beta$-mercaptoethanol did not show important influence on the purified $\alpha$-amylase activity. This can make it obvious that serine residues and disulfide bonds are not essential for the amylolytic activity ${ }^{38}$.

Table 2 Effects of inhibitors and some metal ions on amylase activity

\begin{tabular}{|c|c|c|}
\hline Agent & Concentration (mM) & Relative activity of purified $\alpha$-amylase $(\%) *$ \\
\hline \multirow[t]{3}{*}{ PMSF } & 1 & 77 \\
\hline & 5 & 74 \\
\hline & 10 & 65 \\
\hline \multirow[t]{3}{*}{ DTT } & 1 & 97 \\
\hline & 5 & 93 \\
\hline & 10 & 92 \\
\hline \multirow[t]{3}{*}{$\beta$-mercaptoethanol } & 1 & 96 \\
\hline & 5 & 95 \\
\hline & 10 & 92 \\
\hline \multirow[t]{3}{*}{ EDTA } & 1 & 78 \\
\hline & 5 & 78 \\
\hline & 10 & 64 \\
\hline $\mathrm{Mn}^{+2}$ & 1.5 & 119 \\
\hline $\mathbf{F e}^{+2}$ & 1.5 & 94 \\
\hline $\mathbf{Z n}^{+2}$ & 1.5 & 82 \\
\hline $\mathrm{Mg}^{+2}$ & 1.5 & 86 \\
\hline $\mathbf{H g}^{+2}$ & 1.5 & 38 \\
\hline $\mathrm{Cu}^{+2}$ & 1.5 & 79 \\
\hline $\mathrm{Ca}^{+2}$ & 1.5 & 121 \\
\hline Control & 0 & 100 \\
\hline
\end{tabular}

*Activity remaining after incubation for $30 \mathrm{~min}$ at $37{ }^{\circ} \mathrm{C}$.

\section{Determination of the end products of soluble starch by TLC}

The purified $\alpha$-amylase was incubated with soluble starch for 15, 30 and $240 \mathrm{~min}$. It is seen from the Fig. 6 that the purified $\alpha$-amylase produced by Bacillus mojavensis $\mathrm{SO}-10$ hydrolyzed the soluble starch. There were various end products after hydrolysis of soluble starch by amylase. Maltose (G2), maltotriose (G3), maltotetraose (G4), and maltooligosaccharides occurred after $15 \mathrm{~min}$ and glucose (G1), maltose (G2), maltotriose (G3), maltotetraose (G4), and maltooligosaccharides after 30 min. After $240 \mathrm{~min}$, whole soluble starch hydrolyzed into (G1). Parallel finding was described by Takasaki ${ }^{39}$. These results described that purified $\alpha$-amylase can be used in starch liquefying industry or food industries because of the end products of (G1), (G2), (G3), (G4), and maltooligosaccharides. 


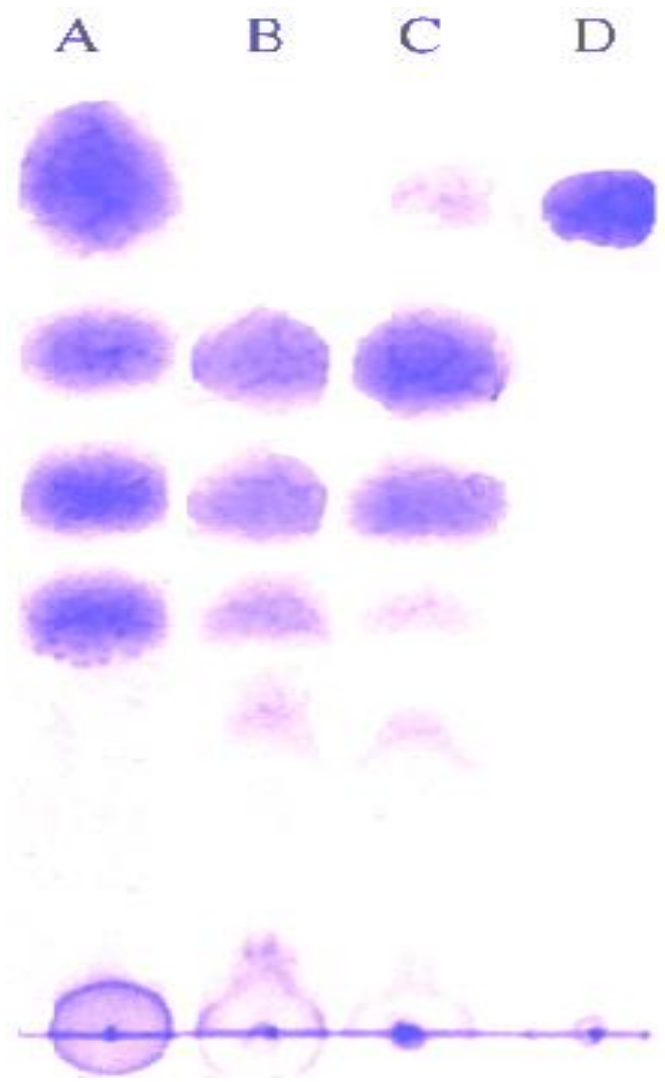

Figure 6 End products of soluble starch by Thin-layer Chromatography TLC. Lane A, glucose (G1), maltose (G2), maltotriose (G3) and maltotetraose (G4); Lane B-D, reaction time for $15 \mathrm{~min}, 30 \mathrm{~min}$ and $240 \mathrm{~min}$, respectively.

\section{Industrial applications of purified $\alpha$-amylase}

The capable of raw starch hydrolyzing of corn and wheat by purified $\alpha$-amylase Purified $\alpha$-amylase capable of hydrolyzing raw starch was examined by defining the percentages of hydrolyzing of corn and wheat starch grains. After $4 \mathrm{~h}$ of incubation, the purified $\alpha$-amylase hydrolyzed the raw wheat and corn grains in the ratio of $36.7 \%$ and $39.2 \%$ respectively. Parallel results were reported by Božić et al. ${ }^{40}$ and Hayashida et al. ${ }^{41}$. Considering the literature, this is the first study to hydrolyze the raw starch by $\alpha$-amylase obtained from B. mojavensis SO-B11. It is too important to degrade the raw starch grains under the gelatinization temperature of starch due to the economic approach. $\alpha$-Amylase produced by $B$. mojavensis SO-B11 can be utilized for hydrolyzing of raw wheat and corn starch in various industries such as food, fermentation and gelatinization of starch. The hydrolyzed raw corn and wheat starch granules were monitored with Olympus CX31 light microscope (Fig. 7). The rate of corn and wheat starch grains decreased after $4 \mathrm{~h}$ of degrading, while the structure of starches grains were moderately damaged. 
Purification and charactarization of amylase
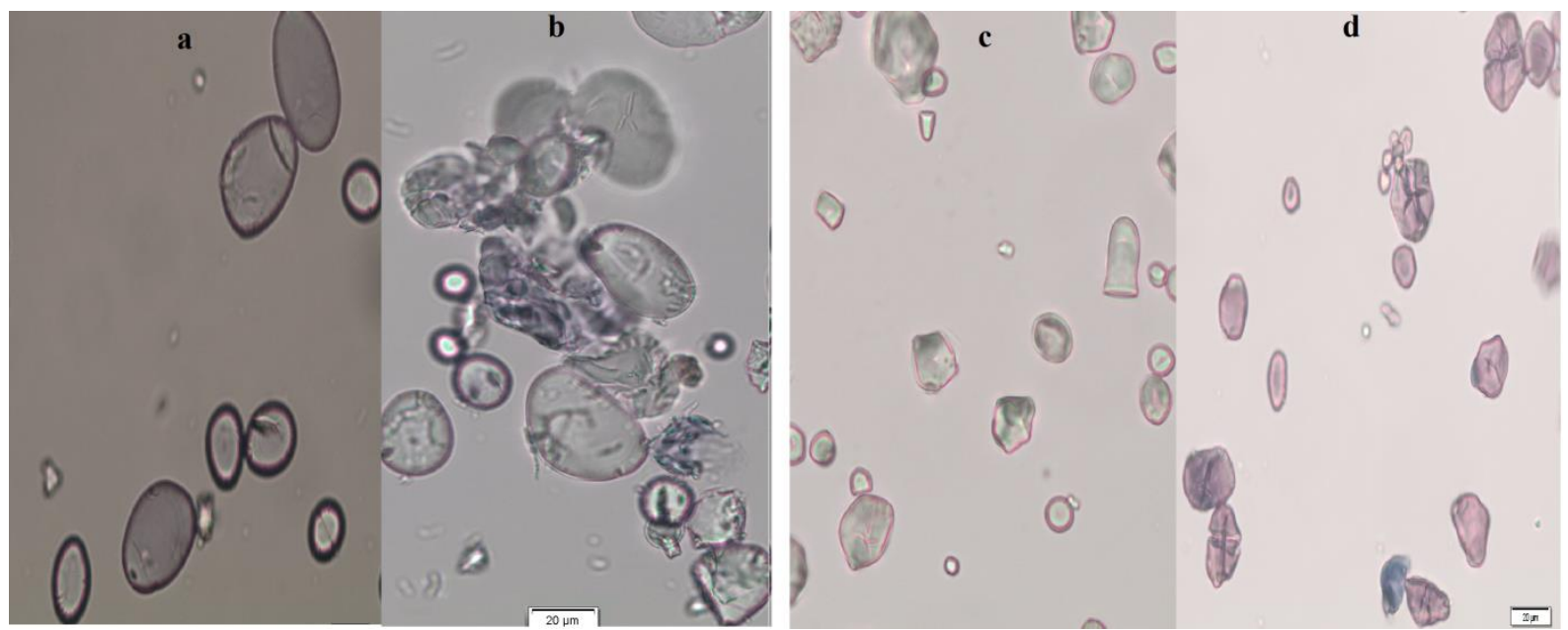

Figure 7 Raw starch hydrolyzing. (A) Corn starch before hydrolyzing; (B) Corn starch after hydrolyzing; (C) Wheat starch before hydrolyzing; (D) Wheat starch after hydrolyzing.

\section{Influence of some commercial detergents and surfactants on purified enzyme activity}

The influence of some surfactants and trading domestic washing detergents on the purified B. mojavensis $\alpha$-amylase was experimented. As demonstrated in Fig. 8, the purified $B$. mojavensis $\alpha$-amylase exhibited significant stability with surfactants and domestic washing detergents such as Omo (44.7\%), Tursil (51.9\%), Alo (63.1\%), SDS (60.9\%), Tween-10 (97.2\%), Tween-40 (99.5) and Triton X-100 (98.2\%) for $60 \mathrm{~min}$ and Omo (41.3\%), Tursil (53.2\%), Alo (73.8\%), SDS (69.7\%), Tween-10 (102.9\%), Tween-40 (99.5\%) and Triton X-100 (101.3\%) for $120 \mathrm{~min}$. Parallel findings were indicated by Goyal et al. ${ }^{42}$ and Pathak and Rekadwad ${ }^{43}$.

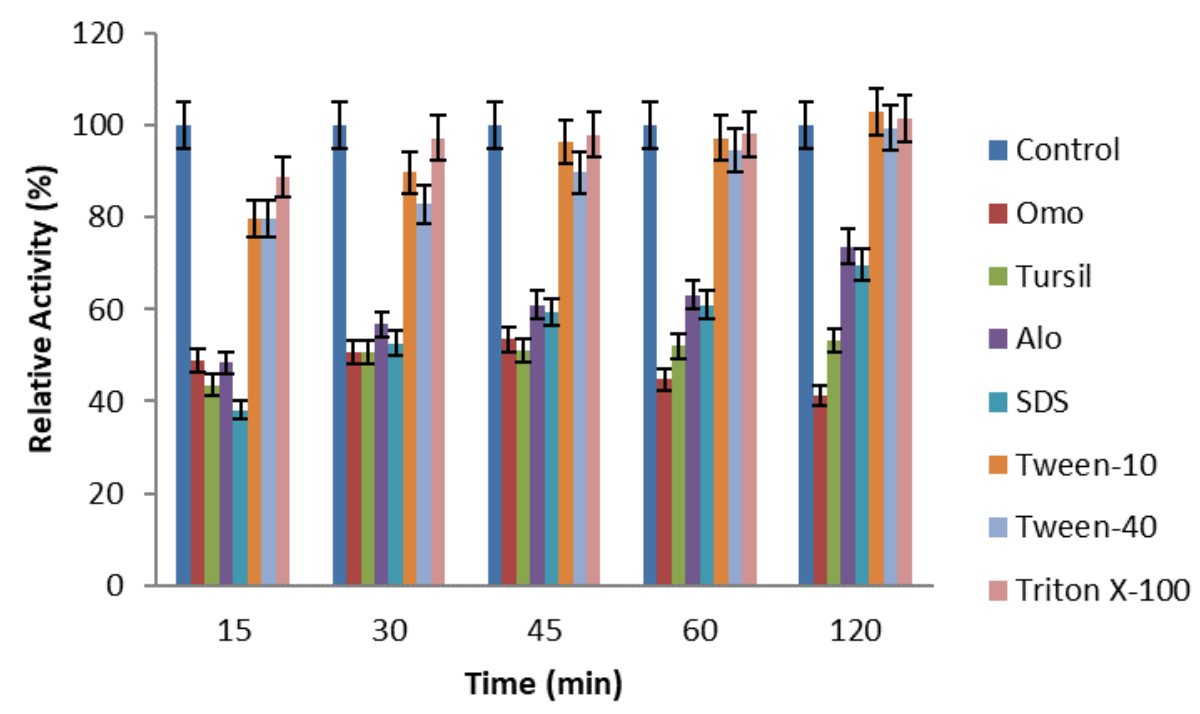

Figure 8 Influence of some commercial detergents and surfactants on purified enzyme activity. 


\section{The starch amounts of immature apple juices (green and red) and theirs clarification by purified enzyme}

Immature starch amounts of red and green apple were tested by using process of Carrín et al. ${ }^{19}$. The starch amounts of immature red apple were determined as $0.59 \mathrm{~g} / \mathrm{L}$ for soluble starch and $3.87 \mathrm{~g} / \mathrm{L}$ for insoluble starch and the starch amounts of immature green apple were determined as $0.52 \mathrm{~g} / \mathrm{L}$ for soluble starch and $3.68 \mathrm{~g} / \mathrm{L}$ for insoluble starch. Digesting of soluble starch of immature red and green apple was experimented for 30, 45, and, $60 \mathrm{~min}$. The degrading percentages of soluble starch contents of red apple and green apple were found as $61 \%$ and $58 \%, 74 \%$ and $71 \%, 85 \%$, and $80 \%$ for 30,45 , and $60 \mathrm{~min}$, respectively. The finding results demonstrated that purified $\alpha$ amylase should be applied in apple juice industry.

\section{CONCLUSIONS}

A thermo and $\mathrm{pH}$ stable $\alpha$-amylase were produced, purified, characterized and utilized for various starch industries. The amylolytic activity did not meaningfully change between $\mathrm{pH}$ ranges of 4.0-8.0 and temperature degrees of 40,50 , and $60^{\circ} \mathrm{C}$ for 120 $\mathrm{min}$. The purified enzyme exhibited stability in the presence of surfactants and metal ions. The purified enzyme obtained from B. mojavensis SO-B11 was capable of hydrolyzing wheat and corn raw starch granules. G1, G2, G3, G4, and maltooligosaccharides were obtained after TLC analysis. In addition, the newly purified alpha amylase should be used in domestic washing detergents and apple juice clarification industries.

\section{ACKNOWLEDGEMENTS}

This study was supported by Scientific Research Projects Unit of Siirt University (Project code: BAP-2011-SIUFED-F3), Turkey.

\section{REFERENCES}

1. Gupta R, Gigras P, Mohapatra H, Goswami VK, Chauhan B, Microbial $\alpha$-amylases: A biotechnological perspective. Process Biochem. 2003; 38: 1599-1616.

2. Roy I, Gupta MN, Hydrolysis of starch by a mixture of glucoamylse and pullulanase entrapped individually in calcium alginate beads. Enzyme Microb. Technol, 2004; 34: 26-32.

3. Balkan B, Ertan F. Production of $\alpha$-Amylase from Penicillium chrysogenum Under Solid State Fermentation by Using Some Agricultural By-Product. Food Technol. Biotechnol. 2007; 45: 439-442.

4. Kumagai Y, Satoh T, Inoue A, Ojima T. Enzymatic properties and primary structures of two $\alpha$-amylase isozymes from the Pacific abalone Haliotis discus hannai. Comp Biochem Physiol B: Biochem Mol Biol. 2013; 164: 80-88.

5. Wiseman A. The application of enzyme in industry. Handbook Enzyme Biotechnol. 1987; 3: 275-373.

6. Lama L, Nicolaus B, Di Donato P, Poli A, Oner ET, Finore I. A raw starch digesting $\alpha$-amylase from the thermophilic Anoxybacillus amylolyticus. Purification and characterization. New Biotechnol. 2009; 25: 91-92.

7. Ozdemir S, Güven K, Baysal Z, Uyar F. Screening of various organic substrates and the development of a suitable low-cost fermentation medium for the production of $\alpha$ amylase by Bacillus subtilis. Food Technol Biotechnol. 2009; 47: 364-369.

8. Ozdemir, S., Matpan, F., Guven, K., Baysal, Z., Production and characterisation of partially purified extracellular thermostable $\alpha$-amylase by Bacillus subtilis in Submerged fermentation (SmF). Prep. Biochem. Biotechnol. 2011, 41, 365-381.

9. Kelly CT, Tigue MM, Doyle EM, Fogarty WM. The raw starch degrading alkaline amylase of Bacillus sp. IMD 370. J Ind Microbiol 1995; 15:446-448. 
10. Itkor P, Tsukagoshi N, Udaka S. Purification and properties of divalent cationdependent raw starch digesting $\alpha$-amylase from Bacillus sp. B. 1018. J Ferment Bioeng 1989; 68:247-251.

11. Singh $\mathrm{H}$, Soni SK. Production of starch gel digesting amyloglucosidase by Aspergillus oryzae HS-3 in solid state fermentation. Process Biochem. 2001; 37:453-459.

12. Shiau JR, Hung HC, Jeang CL. Improving the thermostability of raw starch digesting amylase from a Cytophaga sp. by site directed mutagenesis. Appl Environ Microbiol 2003; 69:2383-2385.

13. Sun HY, Zhao PJ, Ge XY, Xia YJ, Hao ZK, Liu JW, Peng M. Recent advances in microbial raw starch degrading enzymes. Appl. Biochem. Biotechnol. 2010: 160; 988-1003.

14. Ozdemir S, Matpan F, Okumus V, Dündar A, Ulutas MS, Kumru M. Isolation of a thermophilic Anoxybacillus flavithermus sp nov. and production of thermostable $\alpha-$ amylase under solid-state fermentation (SSF). Annals Microbiol. 2012; 62: 13671375.

15. Xie F, Quan S, Liu D, Ma H, Li F, Zhou F, Chen G. Purification and characterization of a novel $\alpha$-amylase from a newly isolated Bacillus methylotrophicus strain P11-2. Process Biochem. 2014; 49: 47-53.

16. Bernfeld P. Enzymes carbohydrate metabolism. In Methods In Enzymol Academic Pres. 1955; 17: 149-158.

17. Laemmli UK. Cleavage of structural proteins during the assembly of the head of bacteriphage T4. Nature. 1970; 277: 680-685.

18. Mitsuiki S, Mukae K, Sakai M, Goto M, Hayashida S, Furukawa K. Comparative characterization of raw starch hydrolyzing $\alpha$-amylases from various Bacillus strains. Enzyme Microb Technol. 2005; 37: 410-416.

19. Carrín ME, Ceci LN, Lozana JE. Characterization of starch in apple juice and its degradation by amylases. Food Chem. 2004; 87: 173-178.

20. Aguloglu Fincan S, Enez B. Production, purification, and characterization of thermostable $\alpha$-amylase from thermophilic Geobacillus stearothermophilus. Starch/Stärke. 2014; 66: 182-189.

21. Abdel-FattahYR, Soliman NA, El-Toukhy NM, El-Gendi H, Ahmed RS, Production, Purification and Characterization of Termostable $\alpha$-amilase Produced by Bacillus licheniformis Isolate AI20. Journal Chemistry. 2012; 2013: 1-11.

22. Shukla RJ, Singh SP. Production optimization, purification and characterization of $\alpha-$ amylase from thermophilic Bacillus licheniformis TSI-14. Starch/Stärke. 2015; 67: 629-639.

23. Murakami S, Nishimoto H, Toyama Y, Shimamoto E, Takenaka S, Kaulpıboon J, Prousoontorn M, Limpaseni T, Pongsawasdi P, Aoki K. Purification and characterization of two alkaline, thermotolerant $\alpha$-amylases from Bacillus halodurans 38C-2-1 and expression of the cloned gene in Escherichia coli. Biosci Biotechnol Biochem. 2007; 71: 2393-2401.

24. Asoodeh A, Chamani JK, Lazgian M. A novel thermostable, acidophilic $\alpha$-amylase from a new thermophilic "Bacillus sp. Ferdowsicous" isolated from Ferdows hot mineral spring in Iran: Purification and biochemical characterization. Int $\mathbf{J}$ Biol Macromol. 2010; 46: 289-297.

25. Michele Michelin TM, Silva VM, Benassi SC, Peixoto-Nogueira LAB, Moraes JM, Leão JA, Terenzi HF, Polizeli Mde L. Purification and characterization of a thermostable $\alpha$-amylase produced by the fungus Paecilomyces variotii. Carbohyd Res. 2010; 345: 2348-2353.

26. Zafar A, Aftab MN, Ud Din Z, Aftab S, Iqbal I, Ul Haq I. Cloning, Purification and Characterization of a Highly Thermostable Amylase Gene of Thermotoga petrophila into Escherichia coli. Appl Environ Microbiol. 2015; 2: 1-18.

27. Pandey A. Nigam P., Soccol C.R. Soccol V.T. Singh D. \& Mohan R. Advances in microbial amylases. Biotechnol Appl Biochem. 2000;31: 135-152.

28. Aguilar G, Morlon-Guyot J, Trejo-Aguilar B, Guyot JP. Purification and characterization of an extracellular $\alpha$-amylase produced by Lactobacillus 
manihotivorans LMG 18010T, an amylolytic lactic acid bacterium. Enzyme Microb Technol. 2000; 27: 406-413.

29. Aguloglu Fincan S, Enez B, Ozdemir S, Matpan Bekler F. Purification and characterization of thermostable $\alpha$-amylase from thermophilic Anoxybacillus flavithermus. Carbohydr Polym. 2014; 102: 144-150.

30. Hamilton LM, Kelly CT, Fogarty WM. Production and properties of the starchdigesting $\alpha$-amylase of Bacillus sp. IMD 435. Process Biochem. 1999; 35: 27-31.

31. Sarkkaya E, Gürgün S. Increase of the $\alpha$-Amylase Yield by Some Bacillus Strains. Turkish J Biol. 2000; 24: 299-308.

32. Kikani BA., Singh SP. The stability and thermodynamic parameters of a very thermostable and calcium-independent $\alpha$-amylase from a newly isolated bacterium, anoxybacillus beppuensis TSSC-1. Process Biochem. 2012; 47: 1791-1798.

33. Lin LL, Chyau CC, Hsu WH. Production and properties of a raw-strach degrading amylase from thermophilic and alkaliphilic Bacillus sp. TS-23. Biotechnol Appl Biochem. 1998; 28: 61-68.

34. Mamo G, Gessesse A. Purification and characterization of two rawstarch-digesting thermostable $\alpha$-amylases from a thermophilic Bacillus. Enzyme Microb Technol. 1999; 25: 433-438.

35. Liu J., Weiguang X, Abdullahi A, Fan WQA, Dingyuan F, Jianjun Z. Purification and Partial Characterization of an Acidic $\alpha$-Amylase from a Newly Isolated Bacillus subtilis ZJ-1 that may be Applied to Feed Enzyme. Prep Biochem Biotechnol. 2015; 45: 259-267.

36. Chakraborty S, Khopade A, Kokare C, Mahadik K, Chopade B. Isolation and characterization of novel $\alpha$-amylase from marine Streptomyces sp. D1. J Mol Catal B: Enzym. 2009; 58: 17-23.

37. Hmidet N, Bayoudh A, Berrin JG, Kanoun S, Juge N, Nasri M. Purification and biochemical characterization of a novel $\alpha$-amylase from Bacillus licheniformis $\mathrm{NH} 1$ Cloning, nucleotide sequence and expression of amyN gene in Escherichia coli. Process Biochem. 2008; 43: 499-510.

38. Shafiei M., Ziaee AA, Amoozegar MA. Purification and biochemical characterization of a novel SDS and surfactant stable, raw starch digesting, and halophilic $\alpha$-amylase from a moderately halophilic bacterium, Nesterenkonia sp. strain. Process Biochem. 2010; 45: 694-699.

39. Takasaki Y. An amylase producing maltotriose from B. subtilis. Agric Biol Chem. 1985; 49: 1091-1097.

40. Božić N, Ruiz J, Santín JL, Vujćić Z. Production and properties of the highly efficient raw starch digesting $\alpha$-amylase from a Bacillus licheniformis ATCC 9945. Biochem Eng J. 2011; 53: 203-209.

41. Hayashida S, Teramoto Y, Inoue T. Production and characteristics of raw potatostarch-digesting $\alpha$-amylase from Bacillus subtilis 65. Appl Environ Microbiol. 1988; 54: $1516-1522$.

42. Goyal N, Gupta JK, Soni SK. A novel raw starch digesting thermostable $\alpha$-amylase from Bacillus sp. I-3 and its use in the direct hydrolysis of raw potato starch. Enzyme Microb Technol. 2005; 37: 723-734.

43. Pathak AP, Rekadwad BN. Isolation of thermophilic Bacillus sp. strain EF_TYK1-5 and production of industrially important thermostable $\alpha$-amylase using suspended solids for fermentation. J Sci Ind Res. 2013; 72: 685-689. 